\title{
Smutek miasta/smutek w mieście. Koncepcja hüzün w prozie Orhana Pamuka
}

Filip Ryba

TEKSTY DRUGIE 2021, NR 1, S. 319-332

DOI: 10.18318/td.2021.1.19 | ORCID: 0000-0002-1624-7257

$\mathbf{K}$ ażde miasto ma niepowtarzalny charakter, w pewnych przypadkach ujawnia się on jednak szczególnie intensywnie. Można go dostrzec w specyficznej architekturze, wyjątkowym mikroklimacie czy zapadającym w pamięć pejzażu. Owa jednostkowość manifestacji podstawowej idei urbanistycznej splata się nie tylko z miejską tkanką, topografią i przestrzenią, lecz także z samymi mieszkańcami. Efektem jest dynamiczna relacja, będąca formą nieustającej wymiany. Metropolia wpływa na własną populację, ta zaś oddziałuje na materię miasta. Pomiędzy dwoma punktami węzłowymi zachodzi nieustanna cyrkulacja znaczeń, a każda ingerencja z zewnątrz doprowadza do zmiany całej struktury. Kiedy w XX wieku upada jedno z największych mocarstw ówczesnego świata, a niedługo potem na gruzach dawnej potęgi zostaje wytworzony zupełnie nowy model podmiotowości, dochodzi do takiej właśnie ingerencji. Pośród ruin Imperium Osmańskiego, w labiryncie ulic i wśród zapuszczonych dzielnic starego Stambułu powoli wzrasta nowa tożsamość. Miniony czas nie daje jednak
Filip Ryba - lic., student studiów azjatyckich na Uniwersytecie Jagiellońskim realizowanych w ramach MISH. Interesuje się współczesnymi problemami kultur bliskowschodnich z perspektywy zachodnich teorii ponowoczesnych. Ostatnio opublikował: Pytając Araba, kim jest. Konstrukty tożsamościowe na Półwyspie Arabskim w reportażach Genowefy Czekały-Muchy (2019). Kontakt: sennr110@gmail.com 
łatwo o sobie zapomnieć, wyrwa między starym a nowym niebezpiecznie zieje pustką. Rozziew staje się częścią nowego konstruktu miejskiego, pozostawiając miejsce na zwątpienie, marazm, hüzün. Czym jest owo uczucie? Jaka jest jego geneza? Jak przebiega jego dynamika? Gdzie jest jego miejsce na planie nowej, tureckiej, tożsamości?

Termin hüzün jest jednym z filarów słynnej prozy Orhana Pamuka Stambut. Wspomnienia i miasto 1 . Próba stworzenia zwartej definicji tego określenia wydaje się jednak niemożliwa, a ontologiczna podstawa zjawiska wymyka się kolejnym próbom dookreślenia. Przez samego twórcę bywa rozmaicie opisywane, przybiera dynamiczne i zmienne formy, ale jest także czymś stosunkowo konkretnym. Wydaje się, że łatwiej dotrzeć do sensów zdeponowanych w tej koncepcji poprzez przyrównywanie i wykazywanie podobieństw oraz fundamentalnych różnic. Hüzün nie stanowi zatem emocji sensu stricto, jego charakter zbiorowy i związek ze światopoglądem sprawiają bowiem, że nie można go interpretować w kategoriach czystego psychologizmu. Ma pewne cechy faktu społecznego ${ }^{2}$, lecz rozumienie tego terminu przez Durkheima relokuje się tu z narzucającej grupy na rozumienie historii, przemiany tożsamościowe oraz ewokującą ten stan topografię i architekturę. Hüzün jest związane również z melancholią, ale jego kolektywny aspekt nie pozwala na pełne utożsamienie. Mimo że żadna z powyższych kategorii nie pełni funkcji ekwiwalentu tureckiego terminu, mogą one stanowić praktyczną podporę dalszych rozważań. Niezależnie od wszystkich wątpliwości konieczna jest próba zdefiniowania tytułowej koncepcji na potrzeby samego artykułu. Hüzün stanowi zatem formę kolektywnej melancholii lub nostalgii, którą odczuwają mieszkańcy Stambułu. Jest to „uczucie, nastrój i kultura”, ${ }^{3}$, co pokazuje, że nawet sama lokalizacja tego stanu zdaje się niejednoznaczna - jest nią zarówno j e d n o s t ka, bo hüzün stanowi formę syntezy stanów emocjonalnych, jak i o t o c z e n i e, ponieważ staje się wtórnym nośnikiem oraz niemym świadkiem historii, a także s p oł e c z eń s two, będące podstawowym wytwórcą kultury. Źródłem hüzün jest podmiot funkcjonujący w zbiorowości, który w ramach przyjętej siatki znaczeniowej odczuwa formę tęsknoty i żalu, jak

1 O. Pamuk Stambuł. Wspomnienia i miasto, przeł. A. Polat, Wydawnictwo Literackie, Kraków 2017. Wszystkie cytaty pochodzą właśnie z tego wydania. W części interpretacyjnej artykułu numery stron podaję w nawiasach.

2 Por. É. Durkheim Co to jest fakt społeczny?, w: Socjologia. Lektury, red. P. Sztompka, M. Kucia, Znak, Kraków 2007, s. 271. 
również przedmiot realny, czyli w tym wypadku miasto, rozumiane zarówno jako całość, jak i zbiór poszczególnych elementów ${ }^{4}$. Korzenie problemu zdają się jednak sięgać do pewnej znaczeniowej wyrwy, jaka powstała na mentalnej osi czasu oraz w tożsamości jednostek funkcjonujących w i wobec danej historii. Brak ciągłości, który ujawnił się pomiędzy Imperium Osmańskim a Republiką Turcji, jest więc fundamentalny. Hüzün pozostaje istotowo zawieszony między przyczyną a skutkiem: choć stanowi element świadomości mieszkańców Stambułu, nieustannie odsyła do przeszłości i własnej genezy. Oznacza to, że hüzün tworzy ważny pomost między minionym a bezustannie konstytuującą się tożsamością zbiorowości.

Chcąc zmierzyć się z tym "stambulskim syndromem", nie mogę zatem bazować na klasycznej strukturze pracy naukowej, skrajnie zracjonalizowana kompozycja i retoryka tego rodzaju projektów stanowiłaby bowiem bardzo wyraźny gest (neo)kolonialny. Odnoszę wrażenie, że aby choć o krok zbliżyć się do bogactwa znaczeń terminu hüzün, należy przyjąć odmienną strategię. W tym celu będę dążył do upłynnienia tekstu, rezygnując tym samym z wyraźnych podziałów strukturalnych, mimo że mogą się one wydać naturalne. Posłużę się także odważniejszą od stosowanej w uniwersyteckim piśmiennictwie metaforyką. Moim celem nie jest w pełni wyczerpujące dookreślenie problemu, będące przecież formą apodyktycznego zamknięcia, uwięzienia, lecz próba spojrzenia z jedynej dostępnej mi perspektywy - peryferyjnej perspektywy zachodniej. Dlatego też zamierzam wykorzystać pewne narzędzia będące w oczywistym sensie owocem działalności akademickiej, nie przypisując im jednak siły absolutnej. Potraktuję je raczej jako swoiste "punkty widokowe", umożliwiające nowe spojrzenia. Ta zwielokrotniona optyka może bowiem pozwolić na wyraźniejsze odczucie (niekoniecznie zrozumienie) fundamentów, na których miałaby się wspierać owa postulowana specyfika koncepcji hüzün. Choć odwołam się do ustaleń z zakresu studiów pamięciowych, afektywnych czy postkolonialnych, żadnej z tych perspektyw nie będę przypisywał znaczenia prymarnego czy apriorycznego. Chciałbym potraktować ten tekst jako pewną próbę zbliżenia się, próbę doświadczenia.

Zanim jednak zupełnie zaplączę się w gęstą sieć znaczeń i kontekstów, należałoby zwrócić uwagę na problemy etymologiczne. Choć słowo hüzün funkcjonuje we współczesnym języku tureckim, ma korzenie arabskie, co świetnie pokazuje, że kemalistowska wizja oczyszczania języka

\footnotetext{
4 Zob. E. Akcan The melancholies of Istanbul " World Literature Today” 2006 vol. 80, no. 6, s. 39-43.

5 Sformułowania tego będę używał jako synonimu terminu hüzün.
} 
z naleciałości kulturowych zakończyła się z miernym skutkiem. Jak donosi sam Pamuk ${ }^{6}$, rok śmierci Chadidży, pierwszej żony Mahometa, jak i Abu Taliba, jego wuja, w Koranie nosi miano „roku smutku”. W określeniu tym wykorzystany został rdzeń دزن który według słownika Hansa Wehra7 związany jest ze smutkiem, żalem czy zmartwieniami ${ }^{8}$.Z kolei zarówno w słowniku Jerzego Łaciny ${ }^{9}$, jak i Janusza Daneckiego i Jolanty Kozłowskiej ${ }^{10}$ akcent został znacznie mocniej położony na „żałości”. Kontekst koraniczny sugeruje jednak wyraźnie, że słowo to odnosi się do głębokiej pustki jako źródła uczucia, w tym wypadku pustki po utracie osoby bliskiej ${ }^{11}$. W dalszej części tekstu Pamuk pokazuje, że obszar znaczeniowy omawianego rdzenia uległ podziałowi - z jednej strony ulokowane zostało rozumienie bardziej ortodoksyjne, związane z krytyką przywiązania do elementów przyziemnych, z drugiej zaś znalazło się pojmowanie mistyczne, połączone z niewysłowioną tęsknotą za bliskością Boga ${ }^{12}$.

Do języka tureckiego słowo to przeszło pod postacią hüzün. Definicja leksykalna doskonale ukazuje pewne relokacje sensów, jakie zaszły w trakcie wchłaniania konceptu przez odmienną kulturę. Według słownika Lucyny Antonowicz-Bauer i Aleksandra Dubińskiego hüzün należy tłumaczyć jako "smutek, tęsknotę, frasunek"13 - uczucie żalu ewoluowało zatem w tęsknotę. Ta położona jest już nieopodal nostalgii, która staje się jednym z kluczowych elementów u Pamuka. Warto jednak zauważyć, że hüzün nie funkcjonuje w rozumieniu melancholii, ta bowiem zostaje wyrażona za pomocą takich określeń, jak „karasevda, melânkoli”4. W Stambule czytamy jednak: „Hüzün wywodzi się z tej samej «czarnej namiętności» co melancholia”. Nienaruszalne jest więc znaczenie relacji obu wspomnianych terminów.

6 O. Pamuk Stambut, s. 121.

7 H. Wehr A Dictionary of modern written Arabic, ed. by J. Milton Cowan, Spoken Language Services, New York 1976, s. 174.

W oryginale: sadness, grief, sorrow, affliction.

J. Łacina Słownik arabsko-polski, Wydawnictwo UAM, Poznań 1997, s. 301.

J. Danecki, J. Kozłowska Słownik arabsko-polski, Wiedza Powszechna, Warszawa 1996, s. 288.

O. Pamuk Stambuł, s. 121.

Por. tamże.

L. Antonowicz-Bauer, A. Dubiński Słownik turecko-polski, polsko-turecki, red. S. Płaskowicka-Rymkiewicz, Wiedza Powszechna, Warszawa 1997, s. 115.

Tamże, s. 343 . 
Pozostając na obszarze szeroko rozumianej problematyki językowej, należy zwrócić uwagę na znaczący gest tłumacza (a właściwie wszystkich tłumaczy) Stambułu. Łatwo zauważyć, że w oryginalnej prozie Pamuka termin hüzün został pozostawiony w tureckim oryginale. Przyczyną takiej decyzji był z pewnością autorski koncept pisarza, w efekcie jednak jeszcze wyraźniej podkreślona została unikatowość przedsięwzięcia. Problemy tłumaczeniowe na obszarze turkologii są oczywiście zbliżone do wszystkich związanych z twórczością egzotyczną w perspektywie europocentryzmu. Zadaniem przekładu jest zatem nie tylko prezentacja dzieła w formie zrozumiałej dla czytelnika, lecz także próba wyrażenia kulturowych zawiłości w ramach systemu językowego, który prawdopodobnie jest niezdolny do ich oddania ${ }^{15}$. Stwierdzenie to pozwala dostrzec także bardziej złożoną dynamikę, jakiej podlega hüzün - z jednej strony dochodzi do próby objaśnienia na linii autor-czytelnik, z drugiej zaś na linii tłumacz-czytelnik. W efekcie wyważonemu konstruktowi dwukrotnie grożą mediacyjne przekłamania i fluktuacje. Ich opis oraz typologię można odnaleźć w tekście Magdaleny Jodłowskiej-Ebo dotyczącym deformacji powstałych w wyniku przekładu dzieł Orhana Pamuka. Na potrzeby naszych rozważań istotne wydają się takie elementy, jak racjonalizacja, niszczenie ukrytych sieci znaczeniowych czy destrukcja sieci elementów rodzimych lub ich egzotyzacja ${ }^{16}$.

Gdy problematyka lingwistyczna została już dosyć ogólnie nakreślona, możliwe staje się przejście do kolejnego istotnego zagadnienia, które pozwoli na nieco jaśniejsze zaprezentowanie tematu we wstępie. Związek hüzün i historii jawi się jako kwestia zupełnie fundamentalna, jako grunt dla rozrastającej się koncepcji. Opisane przez Pamuka zjawisko jest bezpośrednim efektem wydarzeń z przeszłości. Bez ich choćby szczątkowego omówienia nie powiedzie się więc zgłębienie dalszych meandrów tego specyficznego stanu. Krótki wstęp historyczny należałoby rozpocząć od opisu sytuacji Imperium Osmańskiego tuż przed wielką katastrofą. W trakcie drugich rządów konstytucyjnych młodoturcy usiłowali podźwignąć chylące się ku upadkowi państwo. Zmonopolizowanie władzy w 1913 roku umożliwiło wprowadzenie licznych reform ${ }^{17}$. Były to między innymi próby poprawy

15 Zob. D. Chmielowska Problemy przekładu współczesnej prozy tureckiej, w: Studia z dziejów i kultury ludów tureckich, red. T. Majda, Dialog, Warszawa 2013, s. 27-28.

16 Zob. M. Jodłowska-Ebo Wybrane tendencje deformacyjne w tłumaczeniach powieści Orhana Pamuka na język polski, w: tamże, s. 155-164.

17 Zob. E.J. Zürcher Turcja. Od sułtanatu do współczesności, przeł. A. Gąsior-Niemiec, Wydawnictwo UJ, Kraków 2013, s. 121. 
funkcjonowania niewydolnej administracji, działania zmierzające ku laicyzacji sądownictwa i edukacji, a także dążenia do dalszej emancypacji kobiet $^{18}$. Na uwagę zasługuje pewna symetryczność programowa w stosunku do późniejszej strategii kemalistowskiej. Również styl uprawiania polityki w duchu wszechobecnego nacjonalizmu został przejęty i zintensyfikowany w okresie kreowania zupełnie nowego aparatu państwowego i towarzyszącej mu doktryny. Skrajne skupienie uwagi retorycznej na zaprojektowanym narodzie stało się główną przeszkodą podczas próby unowocześnienia oraz liberalizacji gospodarki kraju", skutecznie odstraszając zagranicznych inwestorów. Także pod względem społecznym Imperium Osmańskie wydawało się coraz bardziej niezrównoważone - narastające niezadowolenie Arabów i ciągłe debaty ideologiczne z pewnością destabilizowały państwo ${ }^{20}$. Żadne działania sprawującego realne rządy Komitetu Jedności i Postępu nie mogły już uratować upadającego olbrzyma. Imperium musiało się ugiąć pod naporem europejskich mocarstw i własnej niewydolności. Zawieszenie broni podpisane 30 października 1918 roku w Mudros oznaczało rzeczywistą kapitulację Osmanów ${ }^{21}$. Rozbite państwo pogrążyło się w chaosie, a kolejne ugrupowania przystępowały do rywalizacji o władzę wobec nieznanej wizji zbliżającej się przyszłości.

Przebieg późniejszej wojny o niepodległość nie jest dla naszych rozważań istotny, dlatego pozwolę sobie go pominąćc ${ }^{22}$. W tych działaniach na pozycję nowego lidera wysunął się jeden z dowódców dawnej armii osmańskiej, niejaki Mustafa Kemal, zwany później Atatürkiem. To on z pomocą współpracowników wcielił w życie wizję nowego państwa. W 1923 roku stanął na czele proklamowanej w parlamencie Republiki Turcji jako prezydent i główny ideolog. Mimo protestów środowisk obawiających się monopolizacji władzy został rozwiązany także kalifat, a wszystkim członkom dawnej dynastii osmańskiej nakazano natychmiastowe opuszczenie granic państwa ${ }^{23}$. Gest ten wydaje się szalenie istotny na planie tożsamościowym, gdyż właśnie on

Tamże, s. 121-122.

Por. tamże, s. 127.

Zob. S.J. Shaw, E.K. Shaw Historia Imperium Osmańskiego i Republiki Tureckiej t. 2" 1808-1975, przeł. B. Świetlik, Dialog, Warszawa 2012, s. 442-515.

Zob. E.J. Zürcher Turcja, s. 133.

Por. S.J. Shaw, E.K. Shaw Historia Imperium Osmańskiego i Republiki Tureckiej, s. 515-561.

Zob. E.J. Zürcher Turcja, s. 166-206. 
zapoczątkował pęknięcie, które później nie pozwoli odnaleźć się w rzeczywistości zaprojektowanemu na nowo narodowi.

Nie są dla mnie istotne roszady polityczne, które nastąpiły po akcie inaugurującym powstanie republiki. Aby zrozumieć późniejszy marazm społeczny, należy jednak zwrócić uwagę na kluczowe reformy narzucane w kolejnych latach przez rządy kemalistowskie. Przemiany te miały na celu wytworzenie nowej jakości w ramach projektowanego społeczeństwa, a w konsekwencji radykalne zerwanie z dawnym paradygmatem osmańskim. Zmian wprowadzanych tak dynamicznie przez Atatürka nie należy przy tym pojmować jako zupełnie nowatorskich i wyabstrahowanych, stanowiły bowiem formę bezpośredniego przedłużenia reform tanzimatu i unionistycznych ${ }^{24}$. Strategia budowania nowego państwa została ujęta w program zwany powszechnie „sześcioma strzałami”; stanowił on kręgosłup rodzącej się właśnie republiki i stał się osią kolejnych reform ${ }^{25}$. Pierwszą kategorią był republikanizm, rozumiany jako bezwzględna orientacja antymonarchistyczna. To właśnie na tym gruncie budowano postawę stanowczej wrogości wobec tradycji osmańskiej i związanej z nią bolesnej porażki ${ }^{26}$. Bazę dla całego programu ideowego stanowił jednak kolejny punkt kemalistowskiej ideologii, czyli nacjonalizm, w tym wypadku rozumiany w kluczu etnicznym. Takie pojmowanie wymusiło jednak wytworzenie zupełnie nowego modelu „tureckości”, niezwiązanego z imperialnym dziedzictwem ${ }^{27}$. Do tego celu posłużyła w szczególności „strzała” laicyzacji. Jej ostrze nie było wymierzone bezpośrednio w religię jako taką, lecz w dominującą pozycję ulemów. W efekcie narzucone zostały reformy redefiniujące lokalną tożsamość: zakaz noszenia turbanów i fezów, ograniczenie elementów związanych z religią w przestrzeni publicznej, wprowadzenie do powszechnego użytku nazwisk na wzór europejski, zaprojektowanie nowego języka czy zlikwidowanie bractw religijnych. Cała ta reorganizacja sytemu symbolicznego miała na celu uformowanie nowego, silnego narodu rozumianego całościowo ${ }^{28}$. To konsolidujące podejście zostało w pełni wyrażone w kolejnej kategorii kemalistowskiego programu populizmie. W ramach tej strategii liberalizm skupiony na wolności i dobru

24 Tamże, s. 173.

Zob. A. Adamczyk Ustrój polityczny Turcji w latach 1918-1960, DiG, Warszawa 2013, s. 176-181.

Tamże, s. 181-182.

Tamże, s. 182-189. 
jednostki został zastąpiony utylitarną oraz pragmatyczną wizją działania na korzyść ludu. Dbałość o szeroko rozumiany interes publiczny miała źródło w koncepcji solidaryzmu społecznego Émile'a Durkheima ${ }^{29}$.Tak nakreślona wizja wspólnoty zyskała odbicie w wymiarze gospodarczym, stanowiącym kolejny punkt nowej strategii władz. Etatyzm stał się więc dominującą doktryną ekonomiczną, a pod pretekstem zaspokajania potrzeb narodu kontrolowano i ograniczano ingerencję zagraniczną, jednocześnie blokując emancypację sektora prywatnego ${ }^{30}$. Sposób wprowadzania w życie omówionych powyżej postulatów został zaś opisany w ramach ostatniej „strzały”, która nakazywała dalszą konsolidację osiągnięć rewolucji, a jako podmiot odpowiedzialny za wdrażanie dalszych reform społecznych uznawała klasę rządzącą ${ }^{31}$.

Nie sposób przecenić wpływu, jaki na jednostkę musiały wywrzeć tak dalece posunięte zmiany. Proces wytwarzania nowego obywatela zupełnie przewartościował strukturę tożsamościową, odcinając jednocześnie drogę zakorzenieniu się podmiotu w przeszłości. Brak dostępu do spuścizny przodków wyabstrahował jednostkę z rzeczywistości, pozostawiając ją w swoistym zawieszeniu. Skutecznie wypierana przez władzę, przeszłość powracała jednak niczym nieprzepracowana trauma, a kolejne próby ingerencji w strukturę podmiotu powodowały narastające zagubienie. Tak przygotowany grunt pozwolił na dynamiczny wzrost kolektywnego zjawiska opisywanego w Stambule.

Uporawszy się z podstawowymi kwestiami wstępnymi, możemy wreszcie zbliżyć się do samego tekstu i zniuansować problematykę ujętą przez Pamuka w ramy hüzün. Przeprawę tę należałoby rozpocząć od rozdziału 10, który nieomal w całości został poświęcony zagadnieniom omawianym w tym artykule. Tam też czytamy:

Jeśli miałbym odszukać źródła hüzün doświadczanego w dzieciństwie, zapewne wskazałbym na historię miasta i upadek imperium osmańskiego, a przede wszystkim na to, w jaki sposób wpłynęły one na otaczające mnie „piękne" pejzaże i samych mieszkańców. (s.122)

Por. É. Durkheim O podziale pracy społecznej, przeł. K. Wakar, Wydawnictwo Naukowe PWN, Warszawa 2018. 
Korzenie owego stambulskiego stanu splątane są więc nierozerwalnie z przeszłością. Ta jednak nie ma charakteru czysto abstrakcyjnego, nie jest czasem minionym, do którego nie ma już dostępu i który nie pozwala na zbliżenie. Okres narodzin republiki to czas transformacji miasta. Proces ten niszczył bądź reinterpretował haniebną spuściznę. Pamuk wielokrotnie opisuje pożary willi i ingerencję w topografię. Rozgrywki między dwoma porządkami, osmańskim i tureckim, odcisnęły wyraźne piętno na przestrzeni. Właściwie jest to proces ciągły, Stambuł wciąż funkcjonuje jako arena walki porządków ideologicznych. Ów związek z historią, o którym pisze autor, ma więc także charakter materialny. Wobec tego samo miasto również zdaje się nosić żałobę:

Stambuł wydawał mi się miastem czarno-białym, ponieważ jego uroda i historyczna wielkość nie mogły przebić się na powierzchnię, przykryte ubóstwem, starością i zaniedbaniem. [...] To właśnie tą rezygnacją żywi się zamknięta w sobie dusza Stambułu. (s. 61)

Takie upodmiotowienie jest chwytem często stosowanym przez Pamuka, nie ma jednak na celu wyłącznie zmiany perspektywy czytelniczej, lecz także wykazanie silnej, obustronnej relacji pomiędzy miastem a jego mieszkańcami.

Zależność ta wydaje się skorelowana z pewnymi ontologicznymi i epistemicznymi możliwościami człowieka. Jak zauważa Brian Massumi, ciało ma zdolność odbierania i przyjmowania, może być zarówno przyczyną, jak i skutkiem afektu ${ }^{32}$, który wyraźnie sytuuje się w pobliżu terminu hüzün. Skojarzenie to wynika ze stosunkowo szerokiej definicji afektu będącego wszelkim poruszeniem - niekoniecznie ujmowanym w słowa, często wyłącznie doświadczanym. W tym sensie wspomniana koncepcja może się okazać trafniejsza i bardziej użyteczna od pojęcia emocji czy uczucia ${ }^{33}$, które wymagają ścisłej ingerencji języka nazywającego i stwarzającego rzeczywistość. Miasto stanowi w takim wypadku artefakt emanujący pewnymi afektami, przy jednoczesnym statusie obiektu stałej, nieprzerwanej transformacji sensów. Tak złożona manifestacja urbanistyczna staje się wobec tego zarówno

32 Por. B. Massumi Parables for the virtual: movement, affect, sensation, Duke University Press Books, Durham-London 2002.

33 Zob. J. Tabaszewska Między afektami i emocjami, „Przegląd Kulturoznawczy” 2008 nr 2 (36), s. 265. 
podmiotem, jak i przedmiotem. W sieci zależności i wzajemnego wpływu pozostają więc historia, metropolia oraz jej mieszkańcy.

Kim jednak są sami mieszkańcy? Stambulczycy w oczach narratora stanowią wplątane w niekończący się upadek podmioty. Wychowanie, cudze wspomnienia i dynamiczna przestrzeń kształtują ich tożsamość w taki sposób, że są pozbawieni możliwości emancypacji.Zdają się zawierać pewien brak, który jednocześnie nie może zostać uzupełniony. Kiedy Marianne Hirsch w artykule Żałoba i postpamięć proponuje nowy model pamięci, wywód rozpoczyna od starych fotografii ${ }^{34}$. Stambuł także gęsto wypełniają zdjęcia z domowego archiwum autora oraz świadectwa miejskiej dynamiki ze zbiorów Ary Gülera. Nie tylko to pozorne podobieństwo zdaje się łączyć oba konstrukty. Hirsch pisze: „W moim rozumieniu, postpamięć od pamięci odróżnia pokoleniowy dystans, a od historii głęboka osobista więź"35.

Również współcześni Pamukowi mieszkańcy miasta nie doświadczyli bezpośrednio upadku wielkiego imperium, a ich więź z tym doświadczeniem ma charakter intymny. Hüzün w dużej mierze został w nich wszczepiony przez dominującą narrację, która dotyczyła etapu sprzed ich narodzin. Przestrzeń ontologiczna, na której wzrastały kolejne jednostki, miała w pewnym sensie charakter fantazmatyczny. Jak pisze Hirsch, własne historie zostały zastąpione przez historie poprzedników, a doświadczona trauma stała się niejako bezpośrednim dziedzictwem. Choć koncepcja postpamięci narodziła się w ramach refleksji nad Zagładą, wydaje się użyteczna także w innych kontekstach. Dla Hirsch podstawowym nośnikiem pamięci przekazywanej między pokoleniami stają się fotografie ${ }^{36}, \mathrm{w}$ koncepcji Pamuka charakter mediujący zostaje rozciągnięty na przestrzeń, architekturę czy topografię. Hüzün jest zatem formą postpamięciowego doświadczenia afektywnego, które podlega bezustannej stymulacji.

Nie tylko koncepcja Hirsch zdaje się wnosić ważny aspekt do namysłu nad „stambulskim syndromem”. Michael Rothberg proponuje własny termin - wielokierunkowośćc ${ }^{37}$. Pamięć w jego ujęciu nie jest zastana i jednorodna,

34 Zob. M. Hirsch Żałoba i postpamięć, przeł. K. Bojarska, w: Teoria wiedzy o przeszłości na tle współczesnej humanistyki. Antologia, red. E. Domańska, Wydawnictwo Poznańskie, Poznań 2010, s. 247-280.

Tamże, s. 254.

36 Tamże, s. 255.

37 Zob. M. Rothberg Pamięć wielokierunkowa. Pamiętanie zagłady w epoce dekolonizacji, przeł. K. Bojarska, Wydawnictwo IBL, Warszawa 2015. 
stanowi byt podlegający ciągłym renegocjacjom i zapożyczeniom ${ }^{38}$. Wspomnienie jednego wydarzenia lub traumy z nim związanej staje się płaszczyzną do dyskusji nad zagadnieniami teraźniejszości. Postulowane przez Rothberga niebezpośrednie oraz niejasne powiązanie pamięci i tożsamości uważam za niezwykle istotne ${ }^{39}$. Kiedy wspominałem o dynamice hüzün, starałem się wskazać na wieloaspektowy charakter relacji pomiędzy przedmiotami, podmiotami, ideami i materią. Hüzün stanowi bowiem zarówno jądro „stambulskości",jak też jej peryferie. Tak między innymi manifestuje się zawiłość tych współzależności:

Nasza relacja wobec przeszłości częściowo determinuje to, kim jesteśmy w teraźniejszości, ale nigdy w sposób niezapośredniczony, i nigdy bez niespodziewanych czy nawet niepożądanych konsekwencji, które wiążą nas z tymi, których uważamy za innych. ${ }^{40}$

Tymi „innymi” tureckiej tożsamości byli z pewnością dawni mieszkańcy Imperium Osmańskiego: Grecy, Ormianie czy żyjący w republice do dziś Kurdowie. Znaczenie ich pojedynczych historii, splecionych z losami całego państwa, wywarło wpływ na zmianę perspektywy. Wspominany przeze mnie nieustannie brak ujawnia się również w tym wypadku. Pamuk wielokrotnie pisze o pustce, która została po dawnych mieszkańcach, o ich jednoczesnym zapomnieniu i ciągłej obecności. Częścią hüzün jest więc także poczucie winy bezpośrednio niezawinionej. Rozsadzona zostaje homogeniczność koncepcji, jej wpływy sięgają bowiem daleko poza obręb miasta.

Wracając jednak z przeprawy przez współczesne teorie pamięciowe, pragnę zwrócić uwagę na opresywny rys „stambulskiego syndromu”. Wielokrotnie podkreślałem już społeczne znaczenie tureckiej melancholii, owa wspólnotowość ma jednak bardziej złożony i ambiwalentny charakter. W dalszej części wspomnianego już rozdziału 10 Pamuk pisze: „Stambulski hüzün zaś zabija wszelką myśl o przeciwstawieniu się jednostki społeczeństwu" (s. 139).

Jako element konstytutywny hüzün nie przyjmuje odmowy. Próba odrzucenia tego dziedzictwa zawsze będzie związana z alienacją. Stało się ono

\footnotetext{
38 Tamże, s. 3-4.

39 Tamże, s. 5-6. 
bowiem tak istotnym aspektem radzenia sobie z rzeczywistością, z opisywanym przez narratora brudem i ubóstwem otaczającym gruzy najpotężniejszego niegdyś imperium, że każdy akt protestu wywołuje strach przed zupełnym załamaniem się rzeczywistości. Jednostka nie jest w stanie przeciwstawić się tej dominacji.

Niejednoznaczny charakter hüzün może się odnosić także do niezwykle istotnego aspektu dumy, pozostającej w nierozerwalnym związku ze stambulską tożsamością. Wystarczy wyobrazić sobie wspaniałe wnętrza meczetu Süleymaniye czy oszałamiające piękno pałacu Topkapı, żeby zrozumieć, gdzie zlokalizowane jest źródło afektu stambulskiej dumy. Bezpośrednie dziedzictwo jednego z najpotężniejszych imperiów świata zostało skontrastowane z druzgocącą porażką. Poczucie wartości było jednak bezustannie uwydatniane przez ideologię nowego porządku. Przesunięcie semantyczne, do którego doszło, pozostawiło jednak ogromną wyrwę. Skoro duma powinna wynikać z bycia Turkiem, to gdzie ulokować osmańskie dziedzictwo? Stambulczycy uzupełnili te kemalistowskie wizje o poczucie wartości będące efektem przetrwania:

[...] to oznaczałoby, że stambulczycy nie traktują hüzün jako nieuleczalnej choroby ogarniającej miasto czy nieodwołalnej nędzy, którą trzeba przetrwać jak każdą inną przypadłość, ani nawet jak kłopotliwego bankructwa rozpatrywanego w kategoriach czarno-białych. Oni widzą w nim powód do dumy. (s. 139-140)

Tak więc owo poczucie wartości nie tylko stanowi pewną przyczynę „stambulskiego syndromu", lecz także jest jego skutkiem.

Zapoczątkowane w tym artykule poszukiwania znaczeń w obrębie złożonego Pamukowskiego konceptu hüzün musiały doprowadzić nas do miejsca kluczowego. Niestety, dotarcie do samego jądra tego punktu w ramach dyskursu naukowego i za pomocą narzędzi dlań typowych, wydaje się czymś niemal nieosiągalnym. Esencją tą jest bowiem doświadczenie. Mimo że przybysze nie są w stanie spojrzeć na rzeczywistość poprzez hüzün, istnieje możliwość chwilowej synchronizacji. Jako że materialna tkanka miasta przesycona jest owym afektem, oddziałuje on na każdego obserwatora. Dlatego też Pamuk w wielokrotnie już wspominanym rozdziale 10 tak wiele miejsca poświęca dokładnym opisom miejsc i sytuacji.To właśnie w nich manifestuje się hüzün najwyraźniej, to one stanowią najdokładniejszy możliwy wyraz tego stanu: 
Ale mnie nie interesuje melancholia Stambułu, tylko hüzün, który można dostrzec w każdym z nas. [...] Chcąc go zrozumieć, trzeba umieć dostrzec miejsca i chwile, w których miesza się z tkanką miasta. (s. 126)

Hüzün zatem wytwarza się dopiero w momencie, kiedy dochodzi do bezpośredniego zetknięcia dwóch elementów: smutku odczuwanego przez podmiot i wewnętrznej względem obiektu melancholii ${ }^{41}$.

Tekst ten nie mógłby zostać domknięty bez poruszenia problematyki postkolonialnej i związanych z nią napięć. Kemalizm jako ideologia bez wątpienia stanowi pewną próbę pogodzenia różnych wartości kulturowych. Zmiany, jakie zaszły przez działania inspirowanych nim ruchów politycznych, stały się jedną z istotniejszych kwestii dotyczących hüzün. Brutalna próba stworzenia nowej, patchworkowej tożsamości okazała się brzemienna w skutki, a właściwe jej mantryczne przywoływanie zachodnich wartości stało się integralną częścią owego poczucia smutku. Stambuł od wieków był synonimem pomostu między światem europejskim a Orientem ${ }^{42}$, jemu także przypadła rola swoistego tłumacza. Wytworzona w ten sposób dwoistość odbiła się jednak na mieszkańcach regionu. Dzieła samego Pamuka nierzadko są interpretowane jako próba przekładu i kompilacji wartości pochodzących z różnych porząalków i światów. Owa potrzeba objaśniania tkwi zaś w ramach projektu hüzün.

Za każdym razem, kiedy czytam reprymendy, dyktowane albo pragnieniem europeizacji, albo przywiązaniem do tradycji, przypomina mi sięgłos matki pouczającej brata i mnie: „NIE POKAZUJCIE PALCEM!”. (s. 181)

Pamuk spogląda więc z licznych perspektyw, kieruje swój wzrok zarówno do wewnątrz, jak i na zewnątrz problemu. Dzięki temu projektowany jest stan bycia w hüzün, ale też bycia wobec hüzün.

Ta wyprawa w poszukiwaniu znaczeń „stambulskiego syndromu” doprowadziła na sam skraj lokalnej tożsamości. W pewnym stopniu udało się naszkicować ogólny zarys sieci, w której obrębie ujawnia się hüzün. Ma ona charakter skrajnie topograficzny i oplata miejską tkankę niby tunele podziemnej kolei, przyjmuje także formę relacji między jednostkami związanymi z przestrzenią i historią, ale przede wszystkim stanowi zmienny oraz płynny

41 Por. E. Akcan The melancholies of Istanbul, s. 39-43.

Por. E. Said Orientalizm, przeł. M. Wyrwas-Wiśniewska, Zysk i S-ka, Poznań 2018. 
układ w obrębie wariantywnych, szeroko rozumianych podmiotów i przedmiotów. Postawione we wstępie pytania również zyskały częściową odpowiedź.Źródła hüzün ujawniły się w uwarunkowaniach historycznych, w odepchniętym dziedzictwie, w materialnym otoczeniu, a także w immanentnym jądrze samego podmiotu. Specyfika tureckości i narodowych uwikłań pozwoliła nieco rozjaśnić genezę zjawiska, a relacja pomiędzy poszczególnymi elementami wykazała olbrzymią jego dynamikę. Fragmenty zaczerpnięte z dyskursu naukowego dały możliwość niedoskonałego, lecz pomocnego opisu doświadczenia i jego konotacji. Nieoczywisty termin afektu okazał się przydatny podczas prób opisu. Kontekst współczesnych teorii pamięciowych pokazał natomiast istotny związek hüzün z traumą, wyparciem i pustką oraz znaczący przepływ międzykulturowy i międzypokoleniowy. Z perspektywy tradycji zachodniej istotny wydaje się również wspominany aspekt postkolonialny, bez którego trudno sobie wyobrazić sensowność gestu będącego rdzeniem tego tekstu - gestu zbliżenia się do doświadczenia z pozycji innego (czy raczej nie-swojego). „Stambulski syndrom” ujawnił się w obrębie dominującej narracji i wobec niej. Duma, zaborczość, nieustępliwość i żal ukazały ambiwalentny oraz wielopoziomowy charakter zjawiska. Esencja hüzün wciąż zdaje się jednak umykać. Być może nie są w stanie dosięgnąć jej zimne narzędzia naukowych metodologii, być może skrywa się gdzieś głęboko pomiędzy widokami a sytuacjami, niedostępna dla chłodnych teorii. Badaczowi pozostaje więc jedynie nieustająca, nieskończona i nieustępliwa próba.

\section{Abstract}

\section{Filip Ryba}

JAGIELLONIAN UNIVERSITY (CRACOW)

The Sadness of the City/Sadness in the City: The Notion of Hüzün in Orhan Pamuk's Fiction

Ryba examines the notion of hüzün in Orhan Pamuk's fiction with a focus on the historical and linguistic context. He draws on theories of affect as well as memory and postcolonial studies. His aim is to highlight the multidimensionality and functionality of the notion of hüzün, and to make its complexity accessible to Polish readers.

\section{Keywords}

Orhan Pamuk, hüzün, Istanbul, melancholia, geopoetics 